\section{Total Resection of Inferiorly Located Sacral Chordoma with Posterior Only Approach: Case Report and Review of the Literature}

\author{
Așağı Yerleșimli Sakral Kordomanın \\ Yalnız Posterior Yaklașımla Total \\ Rezeksiyonu: Olgu Sunumu ve \\ Literatürün Gözden Geçirilmesi
}

\begin{abstract}
Chordoma is a primary sacral neoplasm of ectodermal origin and makes up \%14 of all primary bone tumors. It is usually present on the midline cerebrospinal axis and the most common locations are the spheno-clival region and the sacrum. The treatment of primary sacral tumors represents a challenge because of a large tumor mass at presentation and a hemorrhage risk in surgery. Sacral tumors may present a difficult problem to the surgeon who desires to obtain a clear margin of excision. Using the retrorectal fat tissue as a cleavage line in the posterior approach guides the neurosurgeon to resect the tumor totally and reduce the hemorrhage in sacral chordomas. In this case report, we tried to discuss the advantages of using of retrorectal fat tissue as a cleavage line in sacral chordomas under the literature.
\end{abstract}

KEYWORDS: Sacrum, Posterior approach, Retrorectal fatty tissue

\section{ÖZ}

Kordoma ektodermal kaynaklı primer sakral neoplazmdır ve tüm primer kemik tümörlerinin \%1-4'ünü oluşturur. Genellikle serebrospinal aksın orta hattında bulunurlar ve çoğunlukla yerleşim yerleri sfenoklival bölge ve sakrumdur. Primer sakral tümörlerin tedavisi; ilk ortaya çıtıklarında büyük bir kitle oluşturmuş olmaları ve cerrahide kanama riskleri nedeniyle çözülmesi gereken bir sorun olarak durmaktadır. Sakral tümörler, net bir eksizyon sınırı sağlamak isteyen cerrahlar için zorlu bir problem oluşturur. Posterior yaklaşımda retrorektal yağ dokusunun klavaj hattı olarak kullanılması; beyin cerrahına tümörün tümüyle rezeke edilmesi için yol gösterir ve sakral kordomalarda kanamayı azaltır. Bu olgu sunumunda, sakral kordomalarda retrorektal yağ dokusunun klavaj hattı olarak kullanılmasının yararlarını literatür eşliğinde tartışmak istedik.

ANAHTAR SÖZCÜKLER: Sakrum, Posterior yaklaşım, Retrorektal yağlı doku

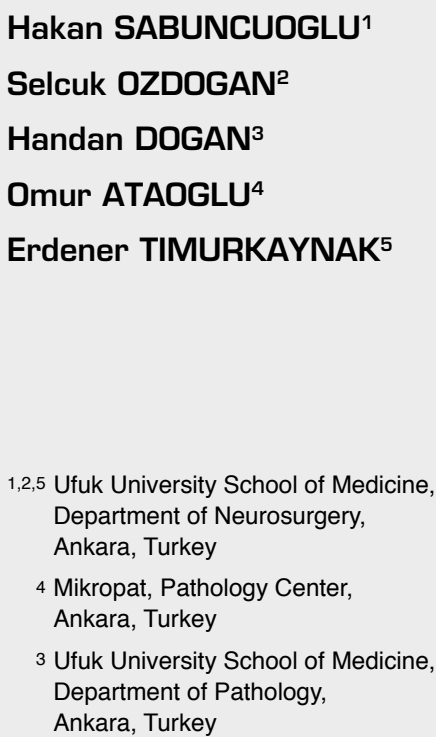

Received : 16.07.2009

Accepted : 29.07.2009

Correspondence address: Hakan SABUNCUOGLU

E-mail: hsabuncuoglu@gmail.com 


\section{INTRODUCTION}

Chordoma is a primary sacral neoplasm of ectodermal origin and makes up $1-4 \%$ of all primary bone tumors (18). It may appear anywhere on the midline cerebrospinal axis; however, the most common locations are the spheno-clival region and the sacrum (9). Some of the sacrococcygeal region located pathologies are chordoma, giant cell tumor, neurofibroma, teratoma, metastasis, myxopapillary epandimoma, myeloma, osteoblastoma, aneurysmal bone cyst, lipoma, osteosarcoma and chondrosarcoma $(1,9)$.

The treatment of primary sacral tumors represents a challenge because of their anatomical location and the relatively high frequency of large tumor mass at presentation (9). Depending on the tumor size, the extent of the operation can vary from simple tumorectomy to total sacrectomy and instrumentation (17). Sacral tumors may present a difficult problem to the surgeon who desires to obtain a clear margin of excision. The problem of local control may be made worse by tumor spill resulting from biopsy or incomplete resection by an inexperienced surgeon. Preservation of neural structure allows ambulation; and using the retrorectal fat tissue as a cleavage line in the posterior approach guides the neurosurgeon to resect the total tumor and reduce the hemorrhage in sacral chordomas.

\section{CASE REPORT}

A 63-year-old man with severe pain in the sacral region was admitted to our neurosurgery department. Pain was aggravated with defecation. His medical history showed a hemorrhoid operation 8 years ago. Because of this, he was examined by the general surgeon and colonoscopy performed in another medical center but nothing was defined as pathological. Only after this was he was referred to our neurosurgery department. In his initial physical exam, a rough palpable mass lesion was present at the sacral region. Upon anal tonus examination, a dense mass lesion was placed on the posterior wall of the rectum. The rectal tonus and perianal examinations were normal. In the radiological evaluation, lumbosacral magnetic resonance imaging (MRI) was performed and the tests revealed the mass arising from $S 4$ to the coccyx, which infiltrated the retrorectal fat tissue partially but not the rectum (Figure 1,2). In reconstructive sacral sagittal computerized tomography (CT), the posterior wall of $\mathrm{S} 4$ was found

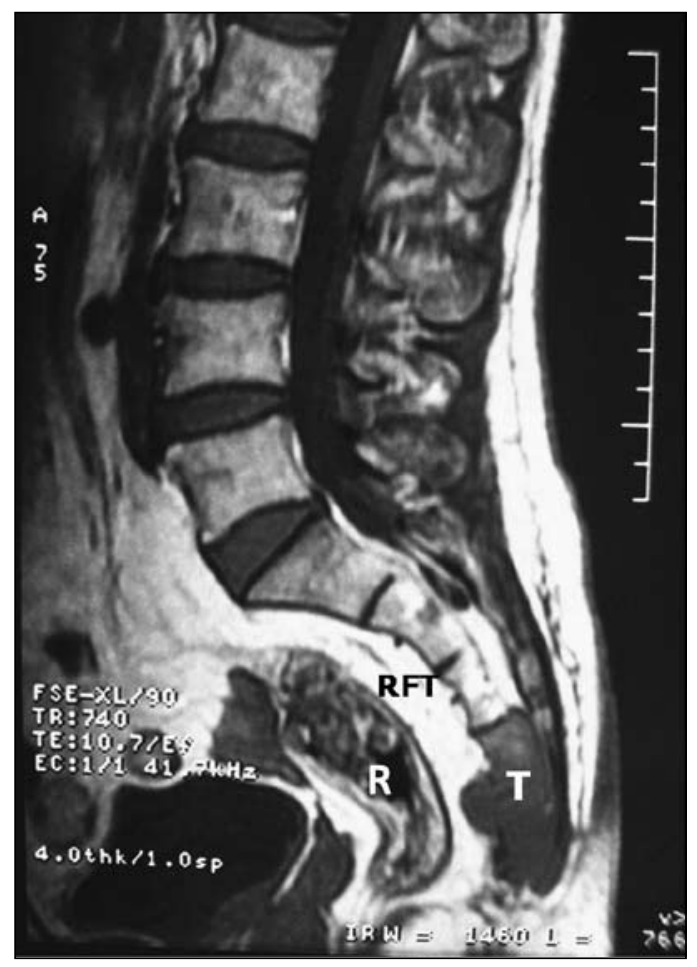

Figure 1: Lumbosacral T2-weighted midsagittal MRI shows the tumor within the body of S4 and S5 vertebral bodies. Slight presacral extension intends retrorectal fat tissue but not rectum. (T: tumor, RFT: retrorectal fat tissue, R: rectum).

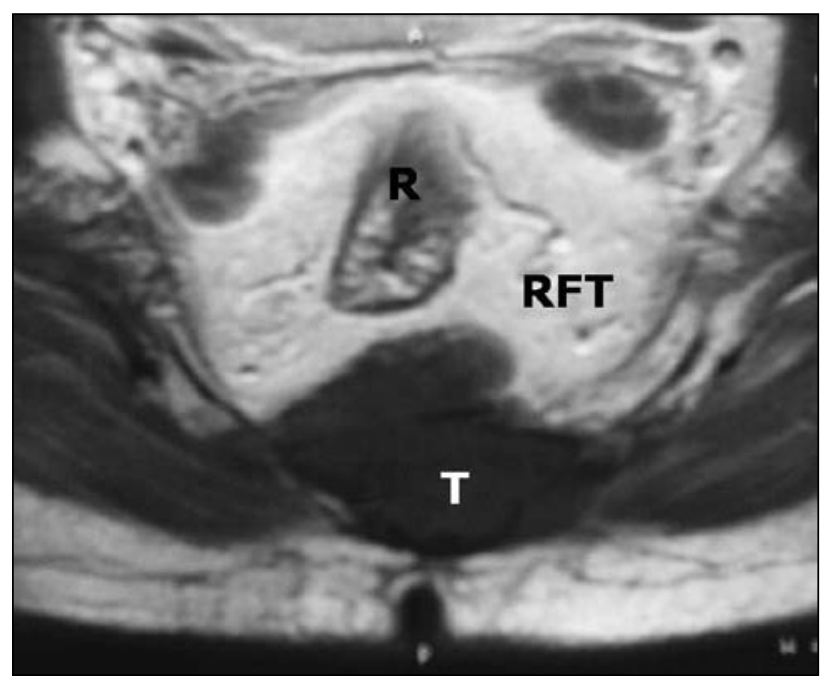

Figure 2: Lumbosacral T2-weighted axial MRI shows involving of retrorectal fat tissue by tumor. The rectum is free from involvement. (T: tumor, RFT: retrorectal fat tissue, R: rectum).

to be destructed and the coccyx was partially invaded (Figure 3,4). All preoperative anaesthesia laboratory studies were normal. The night before surgery, bowel lavage was performed with oral liquid laxative and oral nutrition was cancelled. The anterior approach was excluded from surgical planning because of the 
fat tissue between the rectum and sacral mass and the posterior approach was decided on for the excision of the tumor.

In the operating room, after general anesthesia was administered the patient was turned to the prone position and the skin incision was done in a reverse U shape on the sacral region. The skin flap was laid down; and after dissecting the subcutaneous tissue, the bilateral gluteus maximus and parasacral muscles were identified and dissected laterally. The hard and dark red color tumor was identified on S4-S5 VB and

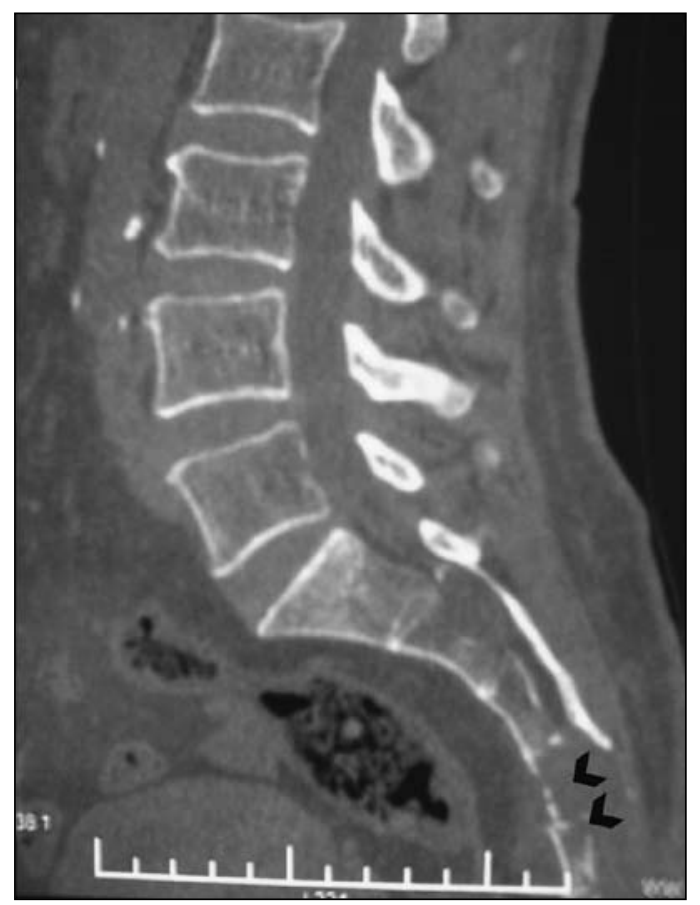

Figure 3: Reconstructive sagittal lumbosacral CT demonstrates bone destruction in S4 and S5 vertebral bodies (arrow heads).

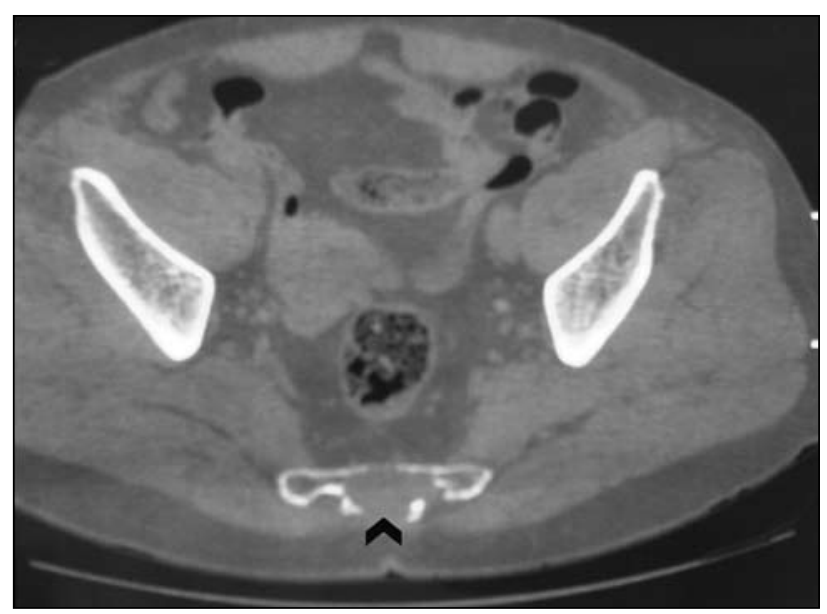

Figure 4: Bone destruction is seen in S4 vertebral body in lumbosacral axial CT (arrow head). the S3 VB was cut transversely with the protection of the curved amputation line using a Kerrison Rongeur. After removing the S3 VB with extensive resection to obtain a tumor-free zone, the retrorectal fat tissue was determined under the tumor; and then the excision was done circumferentially. After the completion of the circumferential excision, blunt dissection was performed between tumor and retrorectal fat tissue (cleavage line); and finally, the tumor was excised completely (Figure $6,7,8)$. During the tumor dissection from the surrounding tissue done under the microscope, the feeding arteries which come from the lateral

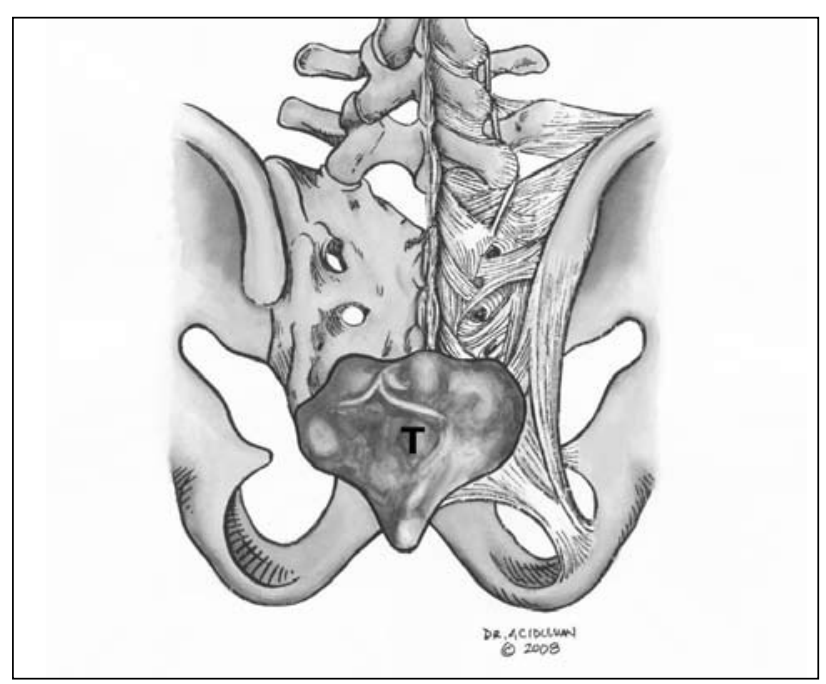

Figure 5: The illustration points out relationship between tumor and the bone tissue. (T: tumor).

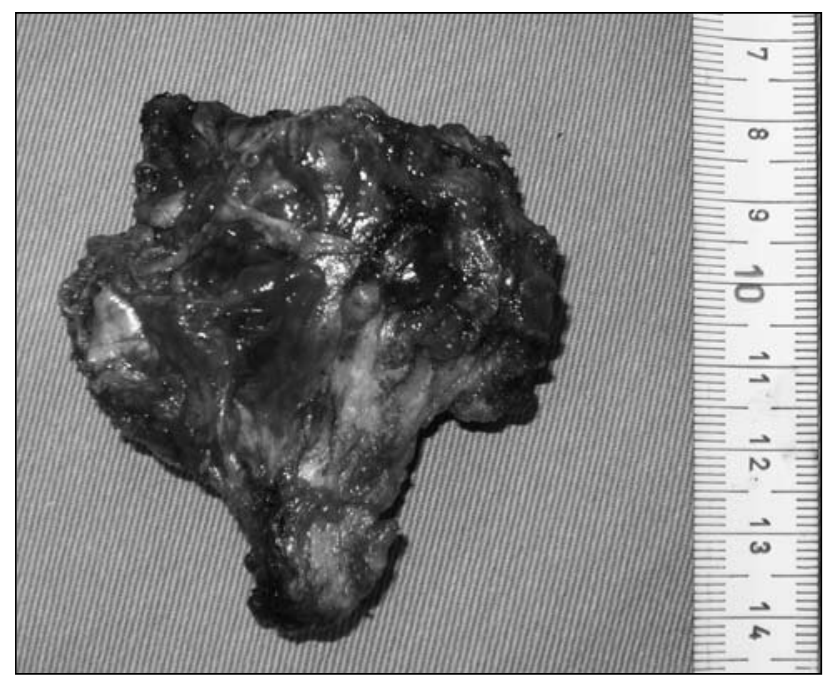

Figure 6: Intraoperative photograph shows the retrorectal fat tissue zone (our cleavage line) after the tumor resection. The border between S2 and S3 vertebral bodies was marked with the arrows in the photograph. 


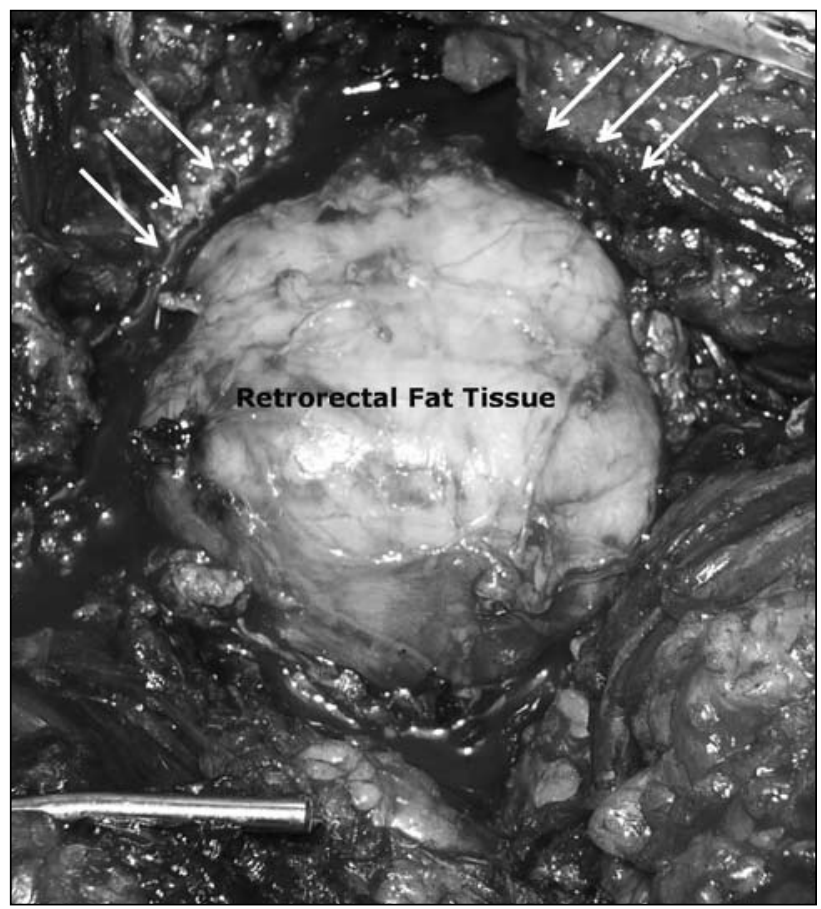

Figure 7: The illustration shows surgical area after the tumor resection. The tumor was excised with tumor free S3 vertebral body. The arrows mark the curved excision line in the sacrum. (RFT: retrorectal fat tissue).

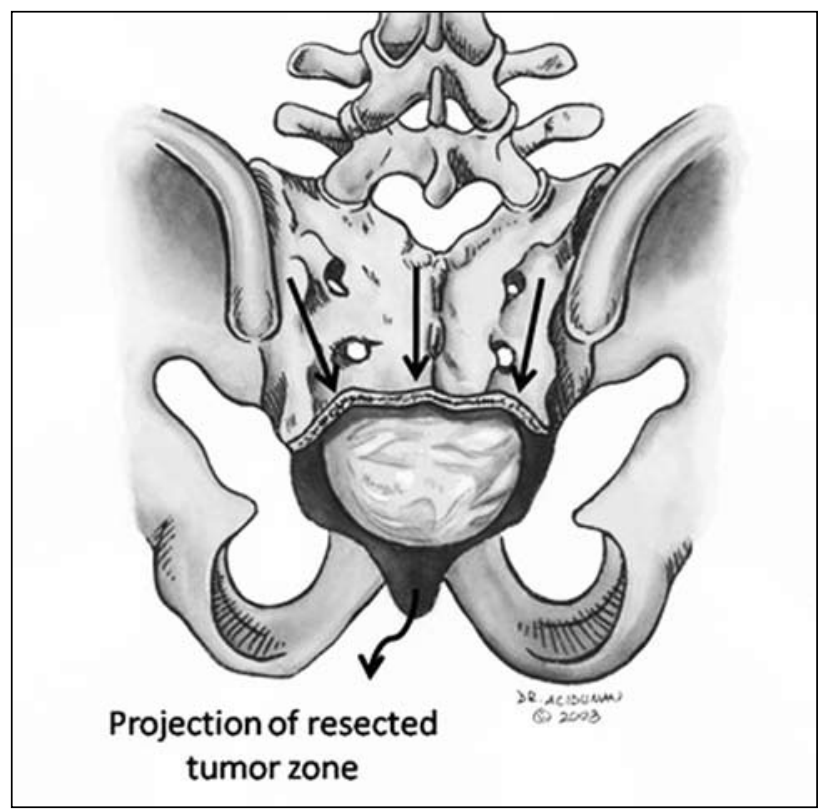

Figure 8: The macroscopic view of the tumor.

and anterior part of the tumor zone were coagulated and cut by using bipolar forceps and microscissors. Then, hemorrhage control was performed and all the layers were closed tightly in a routine manner for protecting the subcutaneously herniation of retrorectal fat tissue. No complications were noted after the operation. In the pathology evaluation, the pathologists reported the tumor as chordoma. When studied in slides, the tumor was seen in cell cords and lobules that were separated by myxoid and chondroid-like stroma. Small round cells with mild cytologic pleomorphism were identified within the lobules. Some of the tumor cells had extremely large vacuolated cytoplasm known as physaliferous cells. Although tumor-invaded bony structures were present in the pathology slides, the surgical specimen border near S3 VB was free from tumor cells and no mitotic activity was determined. Additionally, the tumor cells showed strong immunoreactivity for keratin (Figure 9,10)

The patient was mobilized on the first postoperative day and reported no pain on the sacral

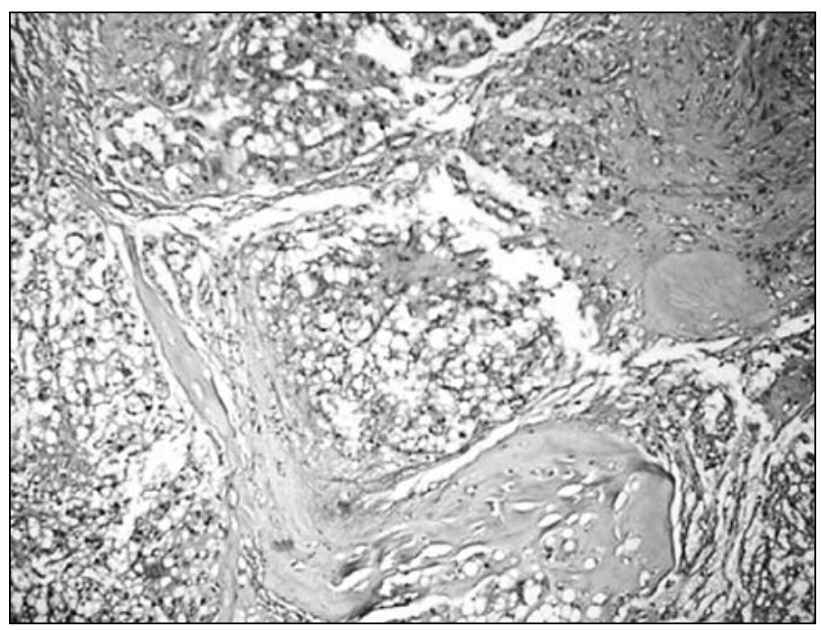

Figure 9: Chordoma having the diagnostic features of lobulation, myxoid and chondroid matrix and vacuolated cells with a chording arrangement. HE $100 x$

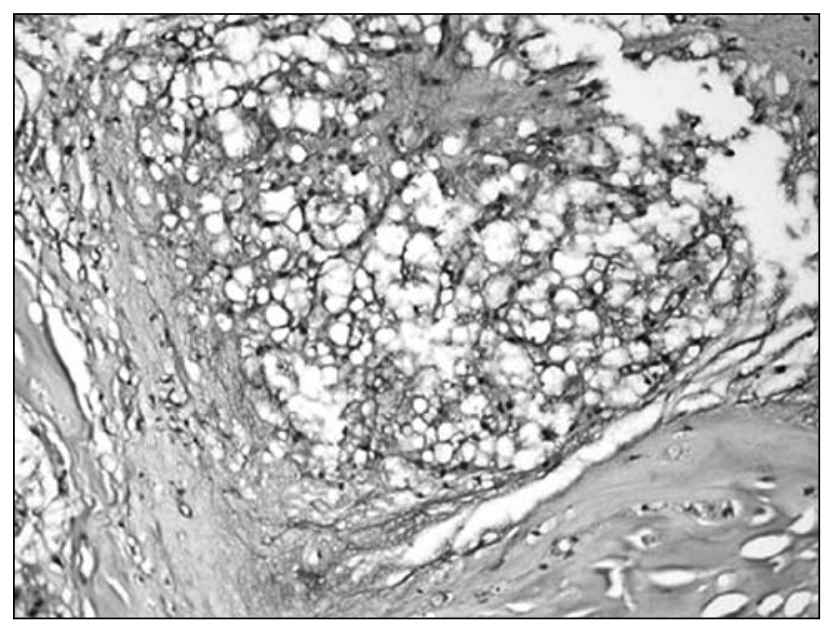

Figure 10: Physaliferous cells which has myxoid matrix and vacuolisation were seen in the figure HE 200x. 
area. He was discharged on the fifth postoperative day. The patient was then referred to the radiation oncology department for local recurrence prevention. No local recurrence was determined during the 10month follow-up period.

\section{DISCUSSION}

Chordoma is a malignant tumor thought to arise from notochordal crests. The estimated yearly chordomaincidenceis 0.5 casespermillioninhabitants. These are slow-growing tumors with a long doubling time. They may appear anywhere on the midline cerebrospinal axis; however, the most common locations are the spheno-clival region and the sacrum (9). About $50 \%$ of chordomas are sacrococcygeal in origin (10). They have little metastatic potential, but considerable local destructiveness $(12,13)$. The most common sites of metastasis include the lungs and the axial skeleton; but unusual appearances like orbital and skin metastases have also been reported (9).

Clinical signs and symptoms may vary depending on the location and the size of the tumor and the extent of neural invasion. Sacrococcygeal chordoma presents a difficult diagnostic and therapeutic problem. Diagnostic procedures consist of radiological and pathologic evaluation. Unfortunately, the lesion is poorly accessible by conventional radiography. Although it is possible to have an adequate demonstration of the bulk of the tumor, the appearance of localized growth could be misleading and soft tissue invasion is often missed in a detailed use of CT for chordoma (12). Contrast-enhanced MRI is the gold standard when it comes to radiological tools (16). It offers several potential advantages in the evaluation of sacrococcygeal chordomas $(11,17)$. An advantage of using MRI studies in chordoma lies in their ability to determine muscle involvement. The images from the sagittal and coronal planes may help to demonstrate the longitudinal extent of the tumor. MRI studies demonstrate a sacral region showing the isointensity to the vertebra in a T1 image with cystic lesion, while a T2 image shows high signal intensity. Although the MRI helps in the characterization of benign and malignant presacral masses and their relationship to pelvic structures, it often cannot distinguish between fibrosis and recurrent pelvic carcinoma in patients managed with surgery or radiation therapy $(4,17)$. In cases of major vessel involvement, preoperative angiography may be necessary to expose the major feeders of the tumor.
The primary therapeutic choice for a sacrococcygeal chordoma is surgical excision. Operations on malignant sacrococcygeal neoplasms seldom achieve radical excision. Furthermore, the surgical approach is difficult because of the site and size of the tumor and its anatomical relation and involvement with surrounding tissues and organs (6). In sacral tumors, resection must be sufficiently extensive to eliminate all possibility of the tumor recurring. Although the sacral chordoma was excised completely in our patient, he was still referred to the radiation oncology department to prevent local recurrence. Local recurrences, however, have often been observed even after total en bloc resection (8). Local control rates have been poor with suboptimal RT doses. The best results were obtained with heavy charged particles. Schoenthaler et al. reported 14 patients treated with helium or neon ions. Four of the 14 patients were treated after gross tumor resection. They reported a 5 -year local control rate of $55 \%$, with a trend for better local control in patients treated with neon ions, compared with helium ions, and for four patients who received RT after gross tumor resection $(3,14)$.

The literature provides different suggestions and experiences about surgical approaches, but no method has become a standard because of the heterogeneity of these tumors. Depending on the tumor size, the extent of the operation can vary from simple tumorectomy to total sacrectomy and instrumentation (9). The location of the tumor within the sacrum determines whether a partial or total sacrectomy will be necessary to achieve a radical excision. Whereas subtotal resection of the sacrum caudal to midportion of the S1 vertebral body (VB) does not destabilize the pelvis, total sacrectomy requires establishment of a bilateral union between the lumbar spine and the ilium, as well as a reconstruction of the pelvic ring $(2,5)$. Although the anterior approach is strongly recommended for sacral chordoma tumors, the posterior approach is adequate for total resection using retrorectal fat tissue as a cleavage line between tumor and rectum. Under the microscope, this cleavage helps the neurosurgeon in protecting the rectum and seeing the feeding arteries of the tumor for cauterization to reduce the hemorrhage. In this case, we preferred to use the Kerrison rongeur, instead of a bone chisel, osteotome or Gigli's saw, because the line of amputation is curved (Figure 7) and manual control makes it possible to feel the consistency of the 
bone and reduce the risk of an intralesional resection and hemorrhage.

Another advantage of the posterior approach is clearly seeing and easily removing the tumor infiltration into the gluteal muscles. Yonemoto et al. mentioned that it is highly possible that residual chordoma infiltrating the gluteal muscles accounts for the local recurrences (18). A precise preoperative assessment of the tumor infiltration into the gluteal muscles by MRI is important for the prevention of local recurrence. Therefore, the resection of sacral tumors using the posterior approach allows for the neurosurgeon to excise the tumor if it involves the gluteal muscles (gluteus maximus and piriformis) (6).

The microsurgical posterior approach is often the preferred way for neurosurgeons because of their familiarity with sacral anatomy. In this approach, the hemorrhage is made to a minimum and the total one piece resection of tumor is made possible with circumferential dissection. For a better prognosis, a wide tumor-free surgical zone should be obtained and all the layers should be closed tightly in a routine manner in order to protect the subcutaneously herniation of perirectal fat tissue.

In conclusion, the posterior approach for sacral tumors is recommended when high sacral involvement $(\mathrm{S} 1 \mathrm{VB})$ is not present and the rectum is not involved because it is a faster and easier procedure to do, with a lower risk of hemorrhage, as compared to the combined anterior abdominosacral approach. It is also possible to manipulate and cut the tumor free line in sacrum for extramarginal resection. Furthermore, the neurosurgeon can feel more confident in the resection and the reduction of the hemorrhage with bipolar cauterization by following the retrorectal fat tissue as a cleavage line.

\section{ACKNOWLEDGEMENT}

The authors are indebted to Ahmet Aciduman (M.D) for his excellent illustrations in this paper.

\section{REFERENCES}

1. Alla AH, Mahadi SI, ElHassan AM, Ahmed ME: A large giant cell tumor of the sacrum. Advantage of an abdomino-sacral approach. Saudi Med J 26(1): 133-135, 2005

2. Blatter G, Ward EGH, Ruflin G: The problem of stabilization after sacrectomy. Arch Orthop Trauma Surg 114:40-42, 1994

3. Chugh R, Tawb H, Luca DR, Biermann JS, Schuetz SM, Baker LH: Chordoma: The nonsarcoma primary bone tumor. Oncologist 12(11):1344-1350, 2007

4. DeLange EE, Fecher RE, Wanebo HJ: Suspected recurrent rectosigmoid carcinoma after abdominoperineal resection. MR imaging and histopathologic findings. Radiology 170: 323-328, 1989

5. Gallia GL, Haque R, Garoznik I, Witham TF, Khavkin YA, Wolinsky JP, Suk I, Gokaslan ZL: Spinal pelvic reconstruction after total sacrectomy for en bloc resection of a giant sacral chordoma: Technical note. J Neurosurg Spine 3:501-506, 2005

6. Gennari L, Azzarelli A, Quagliuolo V: A Posterior approach for the excision of sacral chordoma. The Journal of Bone and Joint Surgery 69-B(4):565-568, 1987

7. Gokaslan ZL, Romsdahl M.M, Kroll SS, Walsh GL, Gillis TA, Wildrick DM, Leavens ME: Total sacrectomy and Galveston L-rod reconstruction for malignant neoplasms: Technical note. J Neurosurg 87:781-787, 1987

8. Ishii K, Chiba K, Watanabe M, Yabe H, Fujimura Y, Toyama $\mathrm{Y}$ : Local recurrence after S2-3 sacrectomy in sacral chordoma: Report of four cases. J Neurosurg 97:1 Suppl: 98-101, 2002

9. Konya D, Gercek A, Toktas ZO, Ozgen S, Yegen C, Pamir NM: Sacrococcygeal chordoma mimicking lipoma: Case Report. World Spine Journal 2(3):148-151, 2007

10. Mindell ER: Chordoma. J Bone Joint Surg (Am) 63:501-505, 1981

11. MoonKL, GenantHK, Helms CA:Musculoskeletal applications of nuclear magnetic resonance. Radiology 147:161-171,1983

12. Rosenthal DI, Scott JA, Mankin HJ, Wismer GL, Brady TJ: Sacrococcygeal chordoma: Magnetic resonance imaging and computed tomography. AJR 145:143-147, 1985

13. Sar C: Total sacrectomy and lumbopelvic reconstruction for primary tumors of the sacrum Acta Orthop Traumatol Turc 35:79-83, 2001

14. Schoenthaler R, Castro JR, Petti PL, Baken-Brown K, Phillips TL: Charged particle irradiation of sacral chordomas. Int J Radiat Oncol Biol Phys 26(2):291-298, 1993

15. Shikata J, Yamamuro T, Kotoura Y, Mikawa Y, Lida H, Maetani S: Total sacrectomy and reconstruction for primary tumors. Report of two cases. J Bone Joint Surg Am 70:122-125, 1988

16. Sung MS, Lee GK, Kang HS, Kwon ST, Park JG, Suh JS, Cho GH, LeeSM, Chung MH, Resnick D: Sacrococcygeal chordoma: MR imaging in 30 patients. Skeletal Radiol 34:87-94, 2005

17. Wetzel LH, Levine E: MR imaging of sacrsl and presacral lesions. AJR 154:771-775, 1990

18. Yonemoto $\mathrm{T}$, Tatezaki S, Takenouchi $\mathrm{T}$, Ishii $\mathrm{T}$, Satoh $\mathrm{T}$, Moriya $\mathrm{H}$ : The surgical management of sacrococcygeal chordoma. Cancer 88(9):2122-2134, 1999 